\title{
Nerve Growth Factor, But Not Epidermal Growth Factor, Increases Fra-2 Expression and Alters Fra-2/JunD Binding to AP-1 and CREB Binding Elements in Pheochromocytoma (PC12) Cells
}

\author{
Valerie Boss, ${ }^{1}$ John D. Roback, ${ }^{2}$ Andrew N. Young, ${ }^{2}$ Linda J. Roback, ${ }^{2}$ Daniela M. Vogt Weisenhorn, ${ }^{2}$ \\ Rafael Medina-Flores, ${ }^{2}$ and Bruce H. Wainer ${ }^{2}$
}

Departments of ${ }^{1}$ Pharmacology and ${ }^{2}$ Pathology, Emory University School of Medicine, Atlanta, Georgia 30329

\begin{abstract}
In pheochromocytoma (PC12) cells nerve growth factor (NGF) and epidermal growth factor (EGF) activate similar receptor tyrosine kinase signaling pathways but evoke strikingly different biological outcomes: NGF induces differentiation and EGF acts as a mitogen. A novel approach was developed for identifying transcription factor activities associated with NGF-activated, but not EGF-activated, signaling, using random oligonucleotide clones from a DNA recognition library to isolate specific DNA binding proteins from PC12 nuclear extracts. A protein complex from NGF-treated, but not EGF-treated, cells was identified that exhibits increased mobility and DNA binding activity in gel mobility shift assays. The binding complex was identified in supershift assays as Fra-2/JunD. The clones used as probes contain either AP-1 or CAMP response element binding (CREB) recognition elements. Time course experiments revealed fur-
\end{abstract}

Growth factors are critical mediators of cellular survival, proliferation, and differentiation. The rat pheochromocytoma (PC12) cell line has been used extensively to study both the biological outcomes induced by growth factors and their associated intracellular signaling cascades. In these cells nerve growth factor (NGF) triggers neuronal differentiation (Greene and Tischler, 1976), but epidermal growth factor (EGF) elicits a proliferative response (for review, see Wells, 1999). Both NGF and EGF activate receptor tyrosine kinases, resulting in receptor autophosphorylation as well as phosphorylation of a targeted pool of downstream molecules exhibiting Src homology 2 (SH2) domains. The SH2 domain-containing molecules recruited by the EGF and NGF receptors are virtually identical. They include Shc and Grb2, which trigger the well known Ras/Raf/MAP kinase pathway, as well as phosphoinositide-3 kinase (PI-3 kinase) and phospholipase $\mathrm{C} 3 \gamma$ (PLC $\gamma)$, which activate additional signaling cascades (for review, see Chao, 1992; Greene and Kaplan, 1995; Marshall, 1995; Whitmarsh and Davis, 1996; Wells, 1999). Given the close similarities in early signaling events initiated by NGF and EGF, the question arises as to how they induce such different biological programs in the same cells.

Much research in this area has focused on identifying early points of divergence in the EGF and NGF signaling pathways (for

Received Aug. 8, 2000; revised Sept. 29, 2000; accepted Oct. 11, 2000.

This work was supported in part by the Wesley Woods Foundation (B.H.W.) and the Alice and Roy Richards Endowed Chair, Emory University (B.H.W.).

Correspondence should be addressed to Dr. Bruce H. Wainer, Department of Pathology, Emory School of Medicine, Wesley Woods Health Center, Room 208, 1841 Clifton Road, Atlanta, GA 30329. E-mail: bwainer@emory.edu.

Copyright (C) 2001 Society for Neuroscience 0270-6474/01/210018-09\$15.00/0 ther differences in NGF and EGF signaling in PC12 cells. NGF elicits a more delayed and sustained ERK phosphorylation than EGF, consistent with previous reports. Both growth factors transiently induce $c$-fos, but NGF evokes a greater response than EGF. NGF specifically increases Fra-1 and Fra-2 levels at 4 and $24 \mathrm{hr}$. The latter is represented in Western blots by bands in the 40-46 kDa range. NGF, but not EGF, enhances the upper bands, corresponding to phosphorylated Fra-2. These findings suggest that prolonged alterations in Fra-2 and subsequent increases in Fra-2/JunD binding to AP-1 and CREB response elements common among many gene promoters could serve to trigger broadly an NGF-specific program of gene expression.

Key words: nerve growth factor; epidermal growth factor; differentiation; transcription factor; Fra-2; PC-12 review, see Marshall, 1995). NGF produces a more prolonged pattern of tyrosine phosphorylation of PLC $\gamma$ and PI-3 kinaseassociated proteins (Blumberg et al., 1995) and a more sustained activation of MAP kinase (also known as extracellular-related kinase; ERK) (Qiu and Green, 1992; Nguyen et al., 1993) than does EGF. Sustained ERK activation is sufficient for neuritogenesis in PC12 cells (Traverse et al., 1994; Fukuda et al., 1995; Yamada et al., 1996). Sustained, but not transient, activation of ERK permits its translocation to the nucleus (Chen et al., 1992; Nguyen et al., 1993; Traverse et al., 1994), where it may modulate gene expression via the phosphorylation of transcription factors.

The present study was designed to detect downstream changes in transcription factor binding activity associated with NGF, but not EGF, signaling. The experimental approach is based on studies in which single transcription factors, such as MyoD, were incubated with random oligonucleotides to identify consensus DNA recognition elements (Blackwell and Weintraub, 1990; Sun and Baltimore, 1991; Gogos et al., 1992). In the present experiments complex nuclear extracts were used in place of single purified transcription factors. Random oligonucleotides were cloned into a DNA recognition element library (DREL); then individual clones were used to probe nuclear extracts from NGFversus EGF-treated PC12 cells and identify NGF-specific protein-DNA binding interactions. This strategy revealed that NGF, but not EGF, mediates a long-term increase in the binding of an AP-1 complex composed of Fra-2 and JunD to both AP-1 and cAMP response element binding (CREB) consensus sites. Such elements are found in a wide variety of gene promoters, and long-lasting differences in AP-1 activity could facilitate a diver- 
gence between the differentiative response evoked by NGF and the mitogenic response induced by EGF.

\section{MATERIALS AND METHODS}

\section{Cell culture and nuclear extraction}

PC12 cells were a gift from Dr. H. C. Palfrey (University of Chicago, IL), subcloned from a parental PC12 line (Dr. Eric Shooter, Stanford University, CA) for maximal neuritogenesis in response to NGF. Cells were grown on plain or collagen-coated plates in DMEM with $10 \%$ fetal bovine serum, $200 \mathrm{mM}$ glutamine, and $50 \mathrm{U} / \mathrm{ml}$ penicillin $-50 \mu \mathrm{g} / \mathrm{ml}$ streptomycin (Complete medium). Cells either were untreated or were incubated in the presence of $2.5 \mathrm{~S} \mathrm{NGF}(50-100 \mathrm{ng} / \mathrm{ml}$; Alomone Labs, Jerusalem, Israel) or 30-50 ng/ml EGF (Promega, Madison, WI) for various times as listed below. Nuclear extracts from PC12 cells were prepared in early experiments via a modification (Abmayr and Workman, 1989) of the protocol of Dignam et al. (1983). In later experiments a different protocol based on the method of Shapiro et al. (1988) was used because of its higher yield. In this procedure growth factor-treated or untreated cells from four $150 \mathrm{~mm}$ plates at $40-70 \%$ confluence were rinsed quickly with room temperature PBS, scraped into $10 \mathrm{ml} /$ plate of ice-cold PBS, pooled, and pelleted at $2000 \times g$ in a $4^{\circ} \mathrm{C}$ centrifuge. Pellets were resuspended in $5 \times$ packed cell volume $(\mathrm{PCV})$ of hypotonic buffer [containing (in mM) $10 \mathrm{HEPES}-\mathrm{KOH}, \mathrm{pH} 7.9,10 \mathrm{KCl}, 0.75$ spermidine, 0.15 spermine, 0.1 EDTA, 0.1 EGTA, 1.0 dithiothreitol, and 0.2 PMSF plus 1 complete mini-protease inhibitor tablet (Roche, Indianapolis, IN) per $10 \mathrm{ml}$ ] and swelled on ice for $10 \mathrm{~min}$. Cells were spun at $2000 \times g$ for $10 \mathrm{~min}$, and the pellet was resuspended in $1 \times \mathrm{PCV}$ of hypotonic buffer to which was added $0.05 \%$ IPEGAL (Sigma, St. Louis, MO). The cells were lysed in a $2 \mathrm{ml}$ Dounce homogenizer. The homogenate was transferred to a centrifuge tube to which was added $0.1 \times$ vol of Sucrose Restore Buffer [containing (in mM) 50 HEPES-KOH, pH 7.9, $10 \mathrm{KCl}$, 0.75 spermidine, 0.15 spermine, 0.2 EDTA, and 1 dithiothreitol plus $67.5 \%$ sucrose and protease inhibitors as above]. The homogenate was spun at $10,000 \mathrm{rpm}$ at $4^{\circ} \mathrm{C}$ in a Beckman JA20 rotor for 1 min with brake. The nuclear pellet was resuspended in (in mM) $10 \mathrm{HEPES}-\mathrm{KOH}, \mathrm{pH} 7.9$, 0.75 spermidine, 0.15 spermine, 0.2 EDTA, 2 EGTA, and 2 dithiothreitol plus $25 \%$ glycerol, $10 \%$ (v/v) saturated ammonium sulfate, and protease inhibitors as above. This resuspension was rocked for $30 \mathrm{~min}$ on ice and spun at $150,000 \times g$ in a Ti70.1 rotor for $90 \mathrm{~min}$. Solid ammonium sulfate $(0.33 \mathrm{gm} / \mathrm{ml})$ was added gradually to the supernatant as it was rocked at $4^{\circ} \mathrm{C}$ over a period of $30 \mathrm{~min}$; then the murky precipitate was allowed to continue rocking for $20 \mathrm{~min}$. After centrifugation at $150,000 \times g$ in at Ti70.1 rotor at $4^{\circ} \mathrm{C}$, the pellet was resuspended in $400-600 \mu \mathrm{l}$ of dialysis buffer [containing (in mM) 20 HEPES-KOH, pH 7.9, $100 \mathrm{KCl}, 0.2$ EDTA, 0.2 EGTA, 2 dithiothreitol, and 0.2 PMSF plus $20 \%$ glycerol] and then dialyzed for several hours or overnight against $200 \mathrm{vol}$ of dialysis buffer. Then the nuclear extract was aliquotted, rapidly frozen, and stored at $-80^{\circ} \mathrm{C}$.

\section{Production of a DNA recognition element library (DREL)}

A plasmid DREL was designed to screen nuclear extracts from PC12 cells for putative transcription factors that exhibit growth factor-specific binding to cloned DNA inserts (see Fig. 1 for schematic). Nuclear extracts from control and NGF-treated PC12 cells were incubated with a pool of radiolabeled double-stranded oligonucleotides consisting of a central random core sequence $25 \mathrm{bp}$ in length, with defined $20 \mathrm{bp}$ flanking regions. The extracts were fractionated by electrophoretic mobility shift assay (EMSA), and the bound oligonucleotides were isolated and amplified by PCR. Selected oligonucleotides were used in successive rounds of PCR amplification. The amplified pool was cloned into pBluescript to produce a DREL. Individual oligonucleotide clones from the DREL were screened by EMSA for differences in gel shift patterns by using nuclear extracts from control, NGF-, and EGF-treated PC12. This protocol is described in detail below.

Production of 65 bp EMSA probes. The oligonucleotide probe mixture (R65) was created as a population of radiolabeled double-stranded oligonucleotides with two defined 20 bp flanking sequences and a $25 \mathrm{bp}$ random core sequence. The upper strand was prepared by programming the specific sequence for the first and last 20 bases and by permitting the oligonucleotide synthesizer to inject all four deoxynucleotides into the reaction column simultaneously for 25 consecutive cycles for the intervening random sequence. The upper strand for R65 is shown below, with the random core sequence designated as N25. A second oligonucleotide (bR2), with covalently attached biotin moiety, was used in forming complementary strands. These and all oligonucleotides were gel-purified before use.

(XhoI) R65: (5')-ATACTACCTCGAGAACGTCC-N25-GGACTCAGAATTCCAGACTC-(3')

bR2: CCTGAGTCTTAAGGTCTGAG-biotin-(5') (EcoRI)

The pool of R65 oligonucleotides was 5 -end labeled with T4 polynucleotide kinase and ${ }^{32} \mathrm{P}-\gamma \mathrm{ATP}$. Complementary strands were formed by annealing the 5'-biotinylated bR2 oligonucleotide to R65, followed by extension with the Klenow fragment of DNA polymerase $\mathrm{I}$ in the presence of all four deoxynucleotides triphosphates. As described below, the biotin tag was used for purification of the R65 oligonucleotides before $\mathrm{PCR}$, and the ${ }^{32} \mathrm{P}$-tag was used to monitor the probe in EMSAs and to track recovery during purification.

EMSA selection and PCR amplification. Nuclear extracts from control and NGF-treated PC12 cells were bound to the R65 probes via the following reaction mixture: $4 \mu \mathrm{g}$ of nuclear extract, $1 \mu \mathrm{g}$ of poly $(\mathrm{dI} / \mathrm{dC})$ : poly (dI/dC), $15 \%$ glycerol, and (in mM) 4 HEPES-NaOH, pH 7.9, 10 Tris-HCl, pH 7.9, 50-150 KCl, 1 EDTA, 1 dithiothreitol, and 0.2 PMSF in a final volume of $20 \mu \mathrm{l}$. The reaction proceeded for $30 \mathrm{~min}$ at $37^{\circ} \mathrm{C}$. In the first round of screening $100 \mathrm{ng}$ of the initial radiolabeled doublestranded R65 oligonucleotide pool was added; in subsequent rounds the input oligonucleotide probes were derived by PCR amplification (see below). After a 20 min binding reaction at $30^{\circ} \mathrm{C}$ the samples were electrophoresed with a $4 \%$ Tris-glycine gel (4\% acrylamide, $0.05 \%$ bis-acrylamide, $2.5 \%$ glycerol, $50 \mathrm{~mm}$ Tris base, $380 \mathrm{~mm}$ glycine, and 2 mM EDTA). The autoradiogram derived from the gel was used to identify and excise the appropriate lanes. For both NGF and control extracts there were three lanes representing binding reactions containing 50,100 , and $150 \mathrm{~mm} \mathrm{KCl}$, respectively. Each lane, excluding the lower regions containing unbound probe, was divided into three to six segments, which were electroeluted at $200 \mathrm{~V}$ for $2 \mathrm{hr}$. Using gel segments, as opposed to a single gel slab containing all of the "bound" oligonucleotides, resulted in higher yields of oligonucleotides after elution and concentration as described below as well as a greater efficiency for the subsequent PCR reactions. Tracking of the radiolabel indicated yields of $90-95 \%$.

To remove PCR inhibitors, we concentrated the R65 oligonucleotide subpool from each gel segment in $0.5 \times \mathrm{SSC}$, using a centrifugal concentrator (Amicon, Beverly, MA), and then incubated it for 45 min with streptavidin-paramagnetic particles (SA-SMP; Promega) to form R65SA-SMP complexes. The complexes were constrained magnetically and washed with $0.5 \times \mathrm{SSC}$ and then treated with $200 \mathrm{~mm} \mathrm{NaOH}$ at $60^{\circ} \mathrm{C}$ to release the radiolabeled single R65 strand from the remainder of the complex. The radiolabeled strand was neutralized with $3 \mathrm{M}$ sodium acetate, $\mathrm{pH} \mathrm{7,} \mathrm{and} \mathrm{then} \mathrm{transferred} \mathrm{to} \mathrm{a} \mathrm{centrifugal} \mathrm{concentrator} \mathrm{to}$ reduce the volume and change the diluent to $\mathrm{H}_{2} \mathrm{O}$. The final yield of each selected single-stranded radiolabeled R65 oligonucleotide subpool was $>80 \%$.

The population of oligonucleotides isolated from each gel segment was amplified in a separate PCR reaction. The forward primer R1 was identical to the first 20 bases of the upper strand of R65 and was 5 '-radiolabeled as described above. The biotinylated oligonucleotide bR2 (see above) was used as the reverse primer. Each reaction contained $5 \mu \mathrm{l}$ of purified R65 eluate; 50 pmol of each primer; $200 \mu \mathrm{M}$ each of dATP, dCTP, dGTP, and dTTP; $1.25 \mathrm{U}$ of $P f u$ DNA polymerase (Stratagene, La Jolla, CA); and $5 \mu \mathrm{l}$ of $P f u 10 \times$ buffer in a final reaction volume of $50 \mu \mathrm{l}$. The entire volume of each eluted R65 subpool was amplified. Amplification conditions were $95^{\circ} \mathrm{C}$ for a single 2 min cycle; then $95^{\circ} \mathrm{C}$ for $30 \mathrm{sec}$, followed by $60^{\circ} \mathrm{C}$ for $30 \mathrm{sec}$ for $10 \mathrm{cycles}$; and finally $60^{\circ} \mathrm{C}$ for a single 7 min cycle. The total number of cycles was kept low to prevent preferential amplification of individual clones. After amplification the reaction volumes for all PCR reactions were combined to include oligonucleotides selected by both NGF-treated and control extracts. They were quantified spectrophotometrically and divided into $100 \mathrm{ng}$ aliquots. These combined oligonucleotide subpools were used as probes for subsequent rounds of EMSA selection. After the fourth round of binding, selection, amplification, and combination, the enriched oligonucleotide populations were ligated into pBluescript (Stratagene).

Cloning of selected R65 oligonucleotides and screening of the DREL by $E M S A$. Each enriched oligonucleotide population was digested with EcoRI and XhoI, ligated into an EcoRI/XhoI double-digested pBluescript plasmid, and maintained in Escherichia coli XL1-Blue (Stratagene). Plasmids were prepared from single colonies, and the inserts were sequenced by dideoxy chain termination, using a commercial kit and protocol (Amersham, Arlington Heights, IL). To PCR-amplify in- 


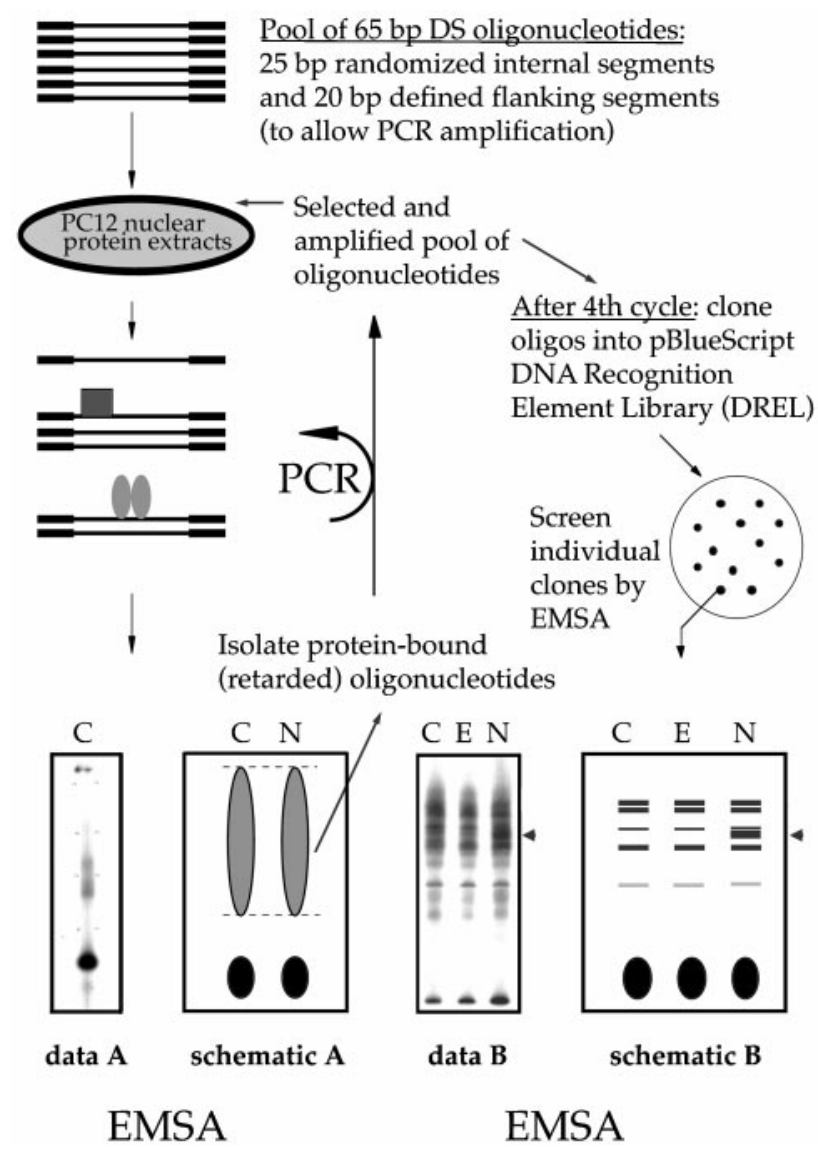

Figure 1. Oligonucleotide clones from a DNA recognition element library (DREL) are used as probes to detect NGF-specific changes in transcription factor binding activity. Nuclear extracts from untreated control $(C)$ PC12 cells or cells treated for $48 \mathrm{hr}$ with NGF $(N)$ are incubated with double-stranded 65 bp oligonucleotides that contain a randomized $25 \mathrm{bp}$ core. The extracts are fractionated by EMSA, and the oligonucleotides bound to the nuclear proteins are isolated. The selected oligonucleotides are amplified by PCR and then serve as input oligonucleotides for another round of the procedure. After four rounds the amplified oligonucleotide pools that bind to extracts from either or both the control and NGF-treated cells are combined and cloned into pBluescript, producing a DREL. Individual clones from the DREL are used as probes in EMSAs to identify differential gel shift patterns when incubated with nuclear extracts from control $(C)$, EGF-treated $(E)$, and NGFtreated $(N)$ PC12 cells. At the bottom left of the figure is a representative sample of the patterns observed in EMSAs in the first four rounds of the protocol. Broad smears without individual bands are observed because the oligonucleotide pool is heterogeneous. The representative sample on the bottom right shows an EMSA probed with a single clone isolated from the DREL. Individual bands are visible, and in this example NGF treatment elicits a different banding pattern (arrowhead) from that observed with either no treatment or EGF.

dividual cloned R65 inserts from pBlueScript, we designed two primers: pBS.UP: $\left(5^{\prime}\right)$-GGAACAAAAGCTGGGTACC- $\left(3^{\prime}\right)$ and pBS.DOWN: (5')-CTGCAG-GAATTCTGAGTCC-(3').

EMSA probes were prepared from the individual clones by using the following reaction mixture: $10 \mu \mathrm{g}$ of purified plasmid DNA; 50 pmol each of the primers pBS.UP and pBS.DOWN; $10 \mu \mathrm{Ci}$ of ${ }^{32} \mathrm{P}$-dCTP (Amersham); $200 \mu \mathrm{M}$ each of dATP, dCTP, dGTP, and dTTP; $5 \mu \mathrm{l}$ of Pfu $10 \times$ buffer; and $1.25 \mu \mathrm{l}$ of $\mathrm{Pfu}$ DNA polymerase. Amplification conditions were $95^{\circ} \mathrm{C}$ for a single $30 \mathrm{sec}$ cycle; followed by $95^{\circ} \mathrm{C}$ for $30 \mathrm{sec}, 55^{\circ} \mathrm{C}$ for $30 \mathrm{sec}$, and $72^{\circ} \mathrm{C}$ for $30 \mathrm{sec}$ for $20 \mathrm{cycles}$; followed by $72^{\circ} \mathrm{C}$ for a single 3 min cycle. Probes were screened by EMSA for growth factor-specific DNA binding proteins in extracts from the nuclei of control, NGF-, and EGF-treated PC12 cells.
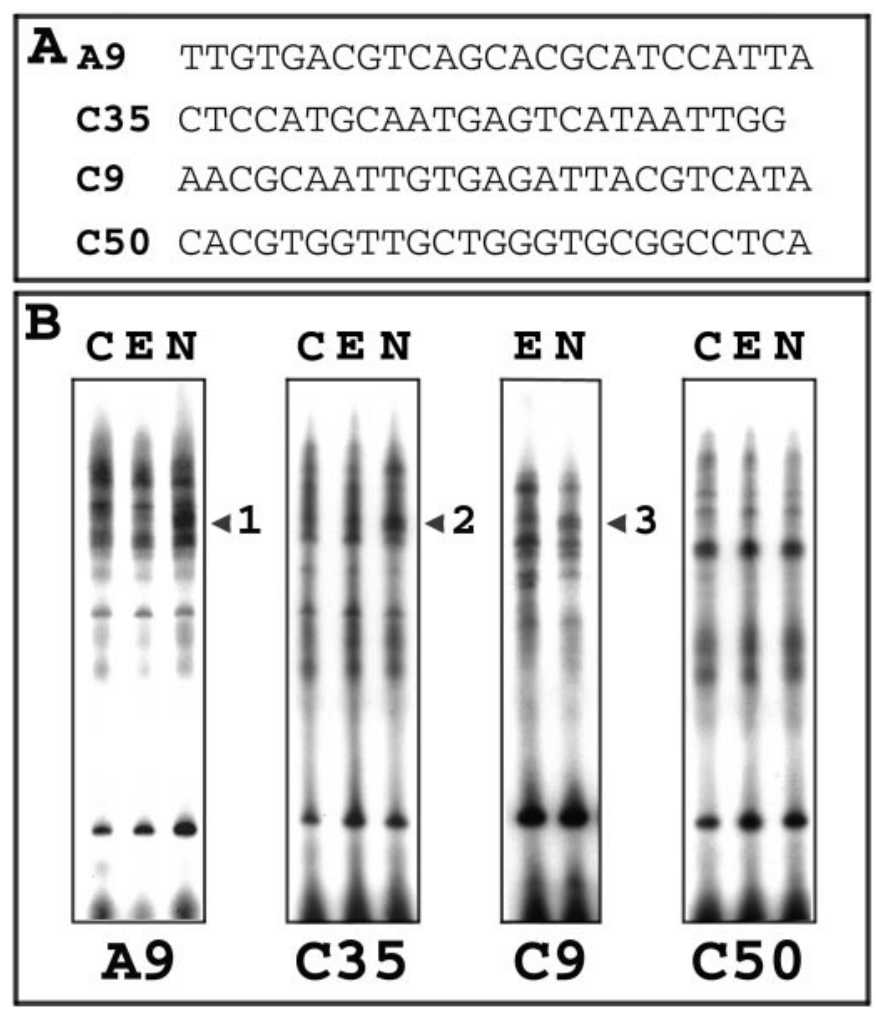

Figure 2. EGF- versus NGF-treated nuclear extracts produce differential gel shift patterns when probed with individual oligonucleotide clones isolated from the DREL. $A$, Core sequences are listed for four of 100 individual DREL oligonucleotides that were tested. $B$, Nerve growth factor-regulated DNA binding activities (NERDs) are detected as differences in individual gel shifts. The A9, C35, and C9 probes recognize complexes from PC12 nuclear extracts for which the binding activity is increased by $24-48 \mathrm{hr}$ of treatment with $\mathrm{NGF}(N)$ as compared with EGF $(E)$ or control $(C)$, denoted as NERDs 1,2 , and 3 (see respective arrowheads). For the majority of probes that were tested, such as C50, nuclear extracts from control or growth factor-treated extracts exhibited the same banding pattern, indicating that proteins bound by the N25 core sequences were not regulated by EGF or NGF.

\section{Analysis of selected oligonucleotides}

Individual R65 clones were identified that showed reproducibly different gel shift patterns for NGF- versus EGF-treated PC12 cells. To characterize two of these clones further, we used shorter versions (35 bp) of the A9 clone (A9WT) and the C35 probe (C35WT), which contained the respective $\mathrm{N} 25$ core sequences. In addition, five oligonucleotides designated $\mathrm{A} 9 \mathrm{~m} 1-\mathrm{A} 9 \mathrm{~m} 5$, generated by mutating sequential $5 \mathrm{bp}$ sites in the A9WT probe, were used in EMSAs as competitors for the labeled A9WT probe. Oligonucleotides for these experiments were purchased from Operon Technologies (Alameda, CA). For EMSAs that used the shorter probes, the polyacrylamide concentration was increased to $6 \%$; the binding reaction was optimized for each probe by adding salmon sperm DNA ( $1 \mu \mathrm{g}$ per binding reaction) and varying the concentration of poly (dI/dC):poly (dI/dC).

EMSA supershift assays were performed as described above, except that nuclear extracts were preincubated with $2 \mu \mathrm{l}$ of water (control) or antibody for $10 \mathrm{~min}$ at room temperature; then probe was added for the binding reaction $\left(37^{\circ} \mathrm{C}\right.$ for $\left.30 \mathrm{~min}\right)$. All antibodies were purchased from Santa Cruz Biotechnology (Santa Cruz, CA), except for the antibody recognizing CREB, which was a gift from Dr. Jeremy Boss (Emory University, Atlanta, GA).

\section{Western blot analysis of nuclear extracts and} whole-cell extracts

Nuclear extracts were prepared as described above for EMSA. Protein concentrations were determined by a kit from Bio-Rad (Richmond, CA). Nuclear proteins $(10-20 \mu \mathrm{g} / \mathrm{lane})$ were diluted with $\mathrm{H}_{2} \mathrm{O}$ to a volume of 


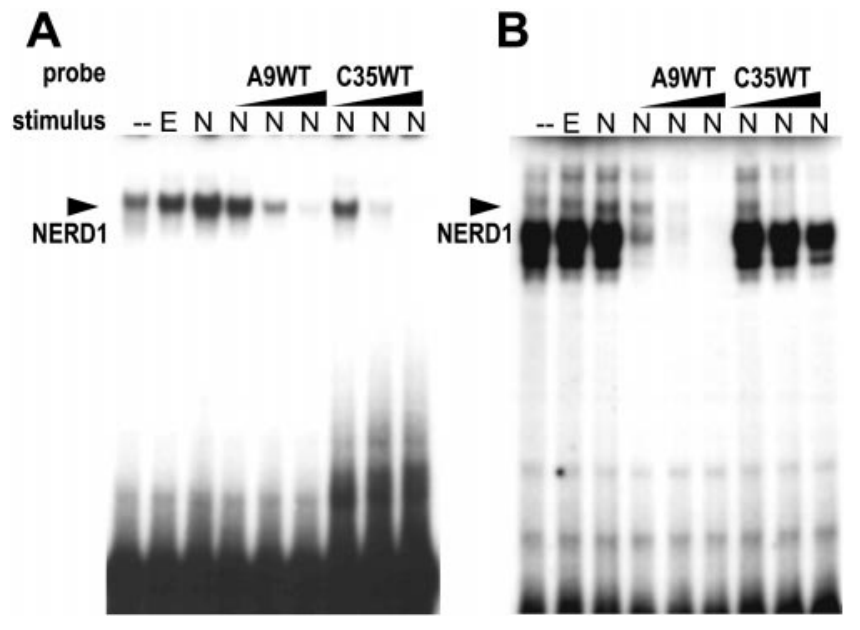

Figure 3. Truncated versions of the $\mathrm{C} 35$ and A9 probes, designated C35WT and A9WT, mutually compete for NERD1 binding. $A$, $B$, Both C35WT and A9WT demonstrate an increase in mobility and intensity of the NERD1 band (arrow) in PC12 nuclear extracts treated for $24 \mathrm{hr}$ with $100 \mathrm{ng} / \mathrm{ml} \mathrm{NGF}(N)$ as compared with $30 \mathrm{ng} / \mathrm{ml} \mathrm{EGF}(E)$ or no drug $(-)$. $A$, Binding of NERD1 to the radiolabeled C35WT probe is competed by increasing concentrations (2-100 ng) of unlabeled A9WT or C35WT. B, Binding of NERD1 to the radiolabeled A9WT probe is competed by increasing concentrations (2-100 ng) of A9WT or C35WT. This figure is a representative example from five separate experiments.

$10 \mu \mathrm{l}$ and then denatured in an equal volume of $2 \times$ loading buffer $[2 \times$ solution $=0.128 \mathrm{~m}$ Tris, $\mathrm{pH} 6.8,2 \% \mathrm{SDS}, 20 \%(\mathrm{v} / \mathrm{v})$ glycerol, $0.02 \mathrm{mg} / \mathrm{ml}$ bromophenol blue, $40 \mu \mathrm{l}$ of $1 \%$ pyronin $\mathrm{Y}$, and $4 \%(\mathrm{v} / \mathrm{v})$ $\beta$-mercaptoethanol] by heating to $95^{\circ} \mathrm{C}$ for $5 \mathrm{~min}$. Equal amounts of protein from control, EGF-, and NGF-treated PC12 cells were separated by SDS-PAGE $(18 \times 16 \mathrm{~cm}$ gels $)$ in which the upper stacking gel contained $4 \%$ acrylamide and the lower resolving gel contained $10-12 \%$ acrylamide (37.5:1::acrylamide:bis ratio). Running buffer was composed of $0.5 \mathrm{M}$ Tris, $0.38 \mathrm{M}$ glycine, and $0.1 \%$ SDS. The SDS-PAGE gel was run at $100 \mathrm{~V}$ for $30 \mathrm{~min}$ and then at $200 \mathrm{~V}$ for $2.5-3 \mathrm{hr}$. An immunoblotPVDC membrane (Bio-Rad) was pretreated with methanol for $15 \mathrm{sec}$ and rinsed in Transfer buffer for 10-15 min. For Western blot the proteins were transferred from the gel to the treated membrane by electrophoresis for $1-2 \mathrm{hr}$ at $200 \mathrm{~V}$ or overnight at $40-50 \mathrm{~V}$ at $4^{\circ} \mathrm{C}$. Transfer buffer contained $0.025 \mathrm{M}$ Tris and $0.192 \mathrm{M}$ glycine. Membranes were rinsed with Tris-buffered saline (TBS) several times, blocked with $3 \%$ milk/TBS, and exposed to primary antibodies against Fra-2 or JunD (Santa Cruz Biotechnology) diluted in block solution overnight at $4^{\circ} \mathrm{C}$. The membranes were rinsed with TBS containing $0.1 \%$ Tween-20, blocked with $3 \%$ milk/TBS, and exposed to a species-appropriate HRPlabeled secondary antibody (Amersham/Pharmacia, Piscataway, NJ) diluted 1:1000 in block solution for $2 \mathrm{hr}$ at room temperature. Then they were rinsed, processed by using a chemiluminescence detection kit from DuPont/NEN, and exposed to film.

A typical Western mini-blot protocol was used in the time course experiments with whole-cell extracts prepared in RIPA-2 buffer with protease inhibitors. The composition of buffers and gels was the same as given above for the larger format gels, but the SDS-PAGE running time was reduced to $1 \mathrm{hr}$. Blots were treated with antibodies and processed as described above. This protocol included primary antibodies specific for the following antigens: Fra-1 and Fra-2 (Santa Cruz Biotechnology), c-fos (Oncogene, Cambridge, MA), and ERK and phospho-ERK (New England Biolabs, Beverly, MA).

\section{RESULTS}

A novel approach was developed for the identification of transcription factors in PC12 cells that are associated with NGFactivated, but not EGF-activated, signaling, using oligonucleotide clones from a DREL as affinity tags to isolate specific DNA binding proteins (Fig. 1). PC12 cells were incubated for $1-3 \mathrm{~d}$ in the presence and absence of NGF (100 ng/ml). Nuclear extracts prepared from these cells were incubated with a pool of labeled
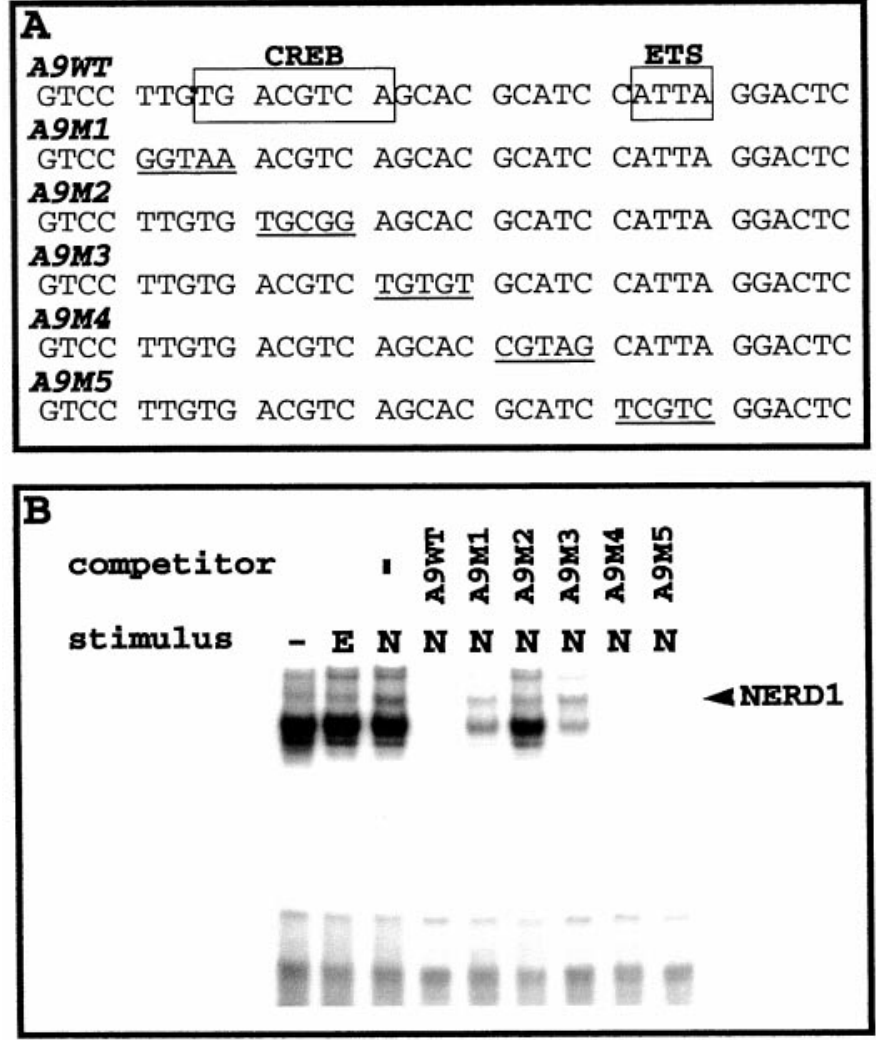

Figure 4. Mutational analysis demonstrates that NERD1 binds to a consensus CREB site in the A9WT probe. This experiment is a representative example of three independent EMSAs in which $(A)$ potential binding sites in the A9WT sequence are mutated, and $(B)$ the mutant probes are used in 100- to 200-fold excess to compete for NERD1 binding (arrowhead) from NGF-treated extracts $(N)$ probed with labeled A9WT. $B$, A9WT, as well as $\mathrm{A} 9 \mathrm{~m} 4$ and $\mathrm{A} 9 \mathrm{~m} 5$ (which are mutated in the Ets binding site), blocks binding of the A9WT probe. In contrast, A91, A9m2, and A9m3 fail to compete for NERD1 binding, suggesting that the mutated CREB site is crucial to NERD1 binding. Control extracts include no treatment $(-)$ and EGF-treatment $(E)$.

double-stranded R65 oligonucleotides containing random $25 \mathrm{bp}$ core sequences. Oligonucleotide subpools that bound to the extracts were selected by EMSA, amplified by PCR, and then combined for use as the input oligonucleotide pool for a subsequent round of the procedure. After four rounds of binding, selection, amplification, and combination, the initially random oligonucleotide pools were enriched for oligonucleotides containing sequences recognized by DNA binding proteins in the PC12 nuclear extracts. The enriched heterogeneous oligonucleotide population was cloned into pBluescript to form a DREL consisting of $\sim 3200$ clones. DNA sequencing of 100 of these individual clones revealed that their random core sequences were unique, indicating that the library was not composed of merely a few highly amplified clones. A few of the clones, such as C35 (see below), contained core sequences of only 24 bp in length, probably owing to PCR error.

Three of the 100 clones that were tested displayed similar gel shift patterns that were reproducibly different for NGF- versus control or EGF-treated cells. These clones were designated as A9, C9, and C35, and their N25 core sequences are listed in Figure $2 A$. The proteins for which the DNA binding activities were regulated by NGF were designated as nerve growth factorregulated DNA binding activities (NERDs). As the gel shift 


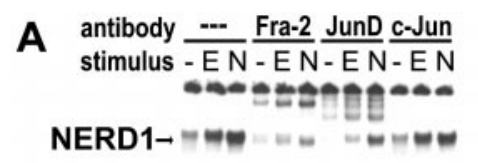

JunB ATF2 CREB Fra-1 C-Fos $-E N-E N-E N-E N-E N$

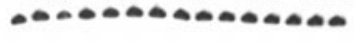

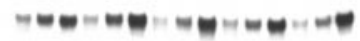
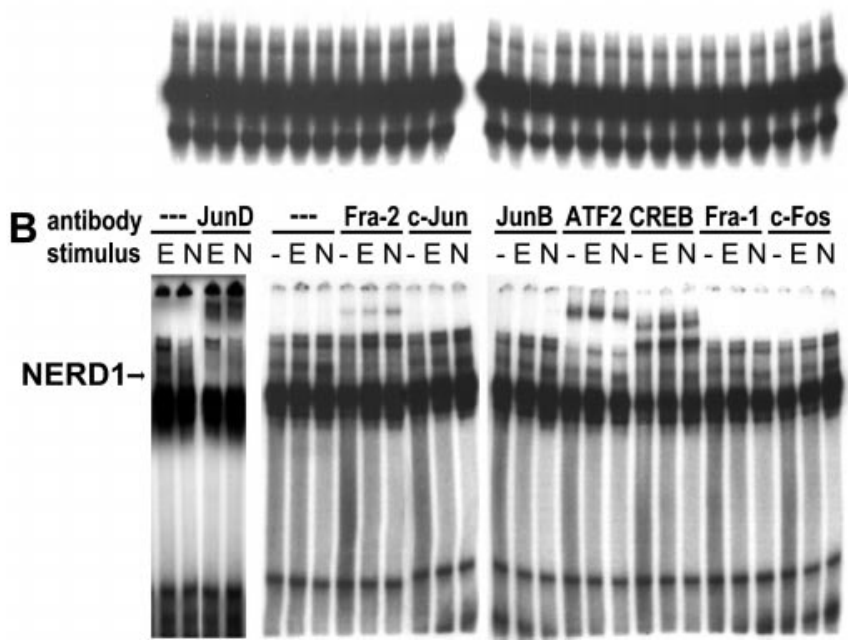

Figure 5. NERD1 binding to C35WT and A9WT probes is supershifted by antibodies that specifically recognize Fra-2 and JunD in EMSAs. $A, B$, NERD1 binding for untreated PC12 cells (-) or cells treated for $24 \mathrm{hr}$ with $30 \mathrm{ng} / \mathrm{ml}$ EGF $(E)$ or $100 \mathrm{ng} / \mathrm{ml} \operatorname{NGF}(N)$ is supershifted by antibodies specific for Fra-2 and JunD, but not by antibodies recognizing CREB, c-Jun, or other members of the AP-1 family. $A$, The C35WT probe detects a single strong band in PC12 nuclear extracts (arrow), which is supershifted partially by antibodies specifically recognizing Fra-2 or JunD. B, The NERD1 band (arrow) also is supershifted by Fra-2 and JunD antibodies when extracts are probed with A9WT. CREB- and ATF-2-specific antibodies supershift other complexes but have no effect on NERD1. This figure is representative of four independent experiments.

patterns in Figure $2 B$ illustrate, NGF, but not EGF, upregulated binding and increased the mobility of nuclear protein complexes binding to clones A9, C35, and C9 (NERDs 1, 2, and 3, respectively). In contrast, the majority of the tested clones did not bind extracts differentially that were treated with either growth factor, as clone C50 typifies (Fig. 2B). In addition, two clones bound NERDs that apparently were downregulated by NGF as compared with EGF (data not shown).

To facilitate the identification of NGF-upregulated NERDs and their specific binding sites, we prepared 35 bp truncated versions (C35WT and A9WT) of the respective C35 and A9 probes (full length $=65 \mathrm{bp}$ ) containing the 25 bp core sequences. The truncated versions of these probes generally elicited fewer bands on EMSAs than the full-length probes (compare Figs. 2, 3). This difference is attributable to nuclear proteins binding to the flanking sequences of the full-length probes, because the core sequences are identical. NGF elicited an increase in both the mobility and intensity of the NERD band in EMSAs with either C35WT or A9WT probes. The truncated oligonucleotides mutually competed for NERD binding (Fig. 3). The A9, C9, and C35 long oligonucleotides also were able to compete away NERD binding to either of the truncated probes (data not shown). These data indicate that NERDs 1, 2, and 3 are the same entity (referred to herein as NERD1). A9WT contains two known protein recognition elements (Fig. $4 A$ ): a CREB-responsive element (CRE; Comb et al., 1986; Delegeane et al., 1987) and an Ets site
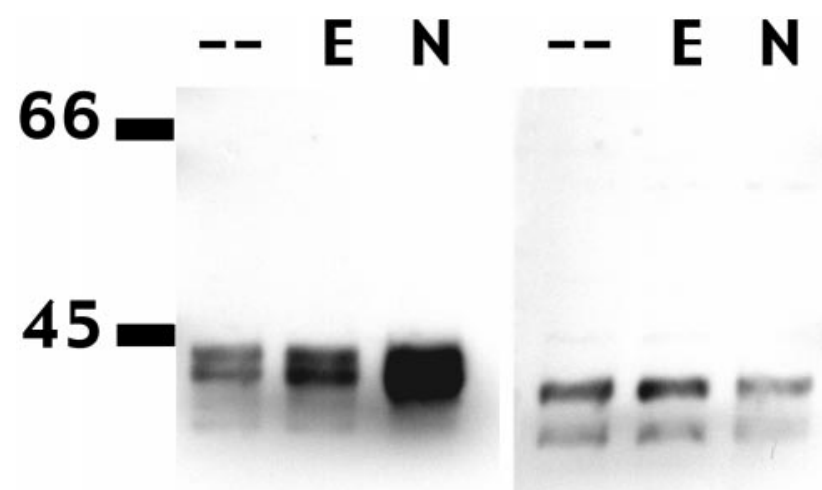

29

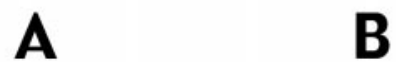

Figure 6. NFG, but not EGF, increases the expression of Fra-2 but has no effect on JunD in PC12 cells. $A$, An antibody that specifically recognizes Fra-2 reveals a series of bands in the 40-46 kDa range in Western blots of PC12 nuclear extracts. All lanes were loaded with $10 \mu \mathrm{g}$ of protein. NGF $(N ; 100 \mathrm{ng} / \mathrm{ml}, 24 \mathrm{hr})$ induces a large increase in the size of upper band(s), producing a broad smear in the 43-46 kDa range. EGF ( $E$; $30 \mathrm{ng} / \mathrm{ml}, 24 \mathrm{hr}$ ) has no effect on Fra-2 expression. $B$, An antibody specific for JunD p39 recognizes a doublet in the $37-40 \mathrm{kDa}$ range. Neither EGF $(E)$ nor NGF $(N)$ affects expression of JunD in PC12 cells. This figure is representative of three independent experiments.

(for review, see Wasylyk et al., 1993). To identify which of the sites in A9WT is recognized by NERD1, we applied a series of five mutant oligonucleotides, A9m1-A9m5, in excess as unlabeled competitors to block interaction between the A9WT probe and nuclear extracts from NGF-treated PC12 cells. As Figure $4 B$ shows, the NERD1/A9WT binding was disrupted by excess unlabeled A9WT as well as by mutants A9m4 and A9m5. In contrast, mutants A9m1-A9m3 failed to inhibit the A9WT-NERD1 interaction. These data indicate that the CRE spanned by the A9m1-A9m3 mutants is necessary for NERD1 binding to the A9WT probe. A search of the TRANSFAC database (Wingender et al., 2000) determined that C35WT contains an AP-1 consensus site, TGAGTCA (Angel et al., 1987; Lee et al., 1987), but no other known recognition elements, suggesting that NERD1 binds to AP-1 recognition sites as well as to CRE. The C9 core sequence also contains a CREB/AP-1-like binding site, ACGTCA, identified by TRANSFAC search.

NERD1 was identified in supershift assays as an AP-1 complex. EMSAs were performed in the presence and absence of antibodies specific for CREB or various members of the AP-1 family. Only antibodies recognizing JunD and Fra-2 supershifted the NERD1 band in EMSAs with either C35WT (Fig. 5A) or A9WT (Fig. 5B). These antibodies did not produce similar bands in EMSAs in the absence of nuclear extracts (data not shown). Antibodies specific for ATF-2 and CREB supershifted other complexes probed with A9WT but had no effect on NERD1 (Fig. $5 B)$. These data indicate that NERD1 is composed of Fra-2 and JunD and concur with previous evidence that AP-1 complexes bind to both CRE and AP-1 binding elements (Sassone-Corsi et al., 1990). Western blots were performed to identify NGF-specific changes in expression or size of the Fra- 2 or JunD proteins. In agreement with previous reports, Fra- 2 was represented by two or more bands ranging from $40-46 \mathrm{kDa}$, with the larger bands representing phosphorylated forms of the protein (Yoshida et al., 1991; Gruda et al., 1994; Suzuki et al., 1994). The exact number 


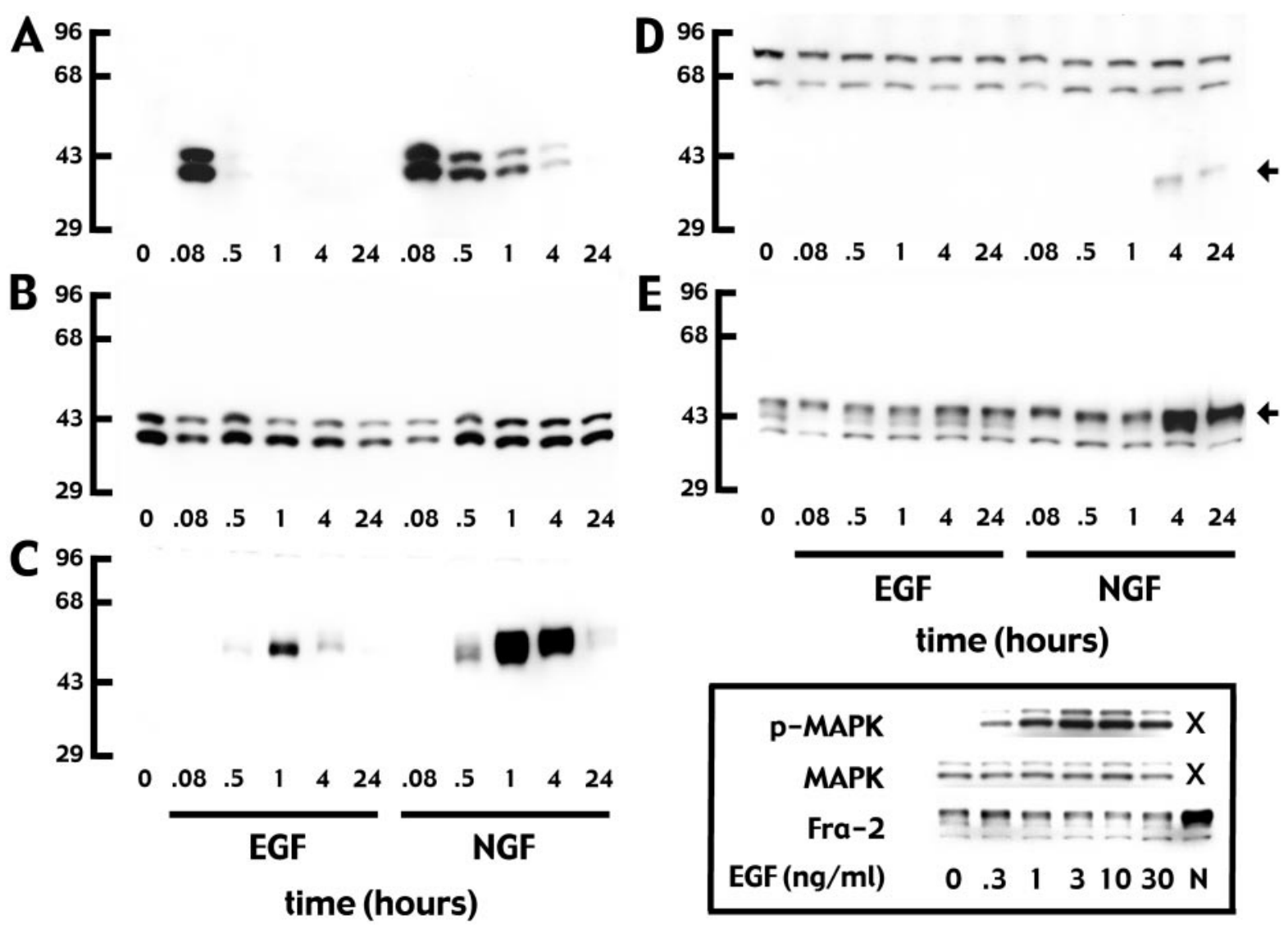

Figure 7. A time course experiment illustrates the differences in phospho-ERK and AP-1 proteins induced by EGF versus NGF in PC12 cells. Western blots of whole-cell extracts were processed with antibodies that specifically recognize phospho-ERK $(A)$, both phosphorylated and unphosphorylated ERK $(B), c$-fos $(C)$, Fra-1 $(D)$, and Fra-2 $(E)$. Cells were untreated $(0)$ or were treated with EGF or NGF for $0.08-24 \mathrm{hr}$, as labeled in the figure. $A$, EGF elicits a very rapid transient phospho-ERK response, whereas NGF elicits a rapid but sustained response. $B$, Overall ERK expression is unchanged by either EGF or NGF treatment. $C$, Both EGF and NGF induce $c$-fos, with a maximal response occurring at 1 hr. For both growth factors this effect is transient, but the NGF response is more robust than that produced by EGF. D, Fra-1 (arrow; the lower band at $\sim 43 \mathrm{kDa}$ ) is induced by NGF, but not by EGF, after a $4 \mathrm{hr}$ delay and the response is sustained at $24 \mathrm{hr}$. The upper bands do not correspond with the reported size for Fra-1 and are nonspecific. $E$, NGF, but not EGF, induces a large increase in the upper Fra- 2 bands (43-46 kDa; arrow) at 4 and 24 hr. Fra- 2 is detectable as two to three bands at 40-46 kDa in control, EGF-, and NGF-treated cells. All lanes were loaded with $20 \mu \mathrm{g}$ of protein. These data are representative of three independent experiments. Inset box (bottom right), EGF increased ERK phosphorylation (p-MAPK), but not overall ERK (MAPK) expression, at 5 min over a concentration range of two log units but did not affect Fra-2 expression at $4 \mathrm{hr}$ at any dose. An example of the NGF-induced Fra-2 response at 4 hr is included in the same blot for comparison. All lanes were loaded with $10 \mu \mathrm{g}$ of protein. This illustration is representative of three independent experiments.

of bands varied among experiments, although there was always a faint band or smear at $\sim 40 \mathrm{kDa}$ and at least one other band at 43-46 kDa. NGF, but not EGF, markedly increased the size of the upper band (Figs. 6A, 7E). In contrast, neither EGF nor NGF induced changes in JunD (Fig. 6B).

Time course experiments were performed to examine the relationship between NGF and EGF receptor activation, the duration of the associated ERK response, and the expression of AP-1 proteins in PC12 cells. As Figure 7 illustrates, EGF elicited a very transient increase in phosphorylated ERK (not detectable after $30 \mathrm{~min}$ ) and a transient increase in $c$-fos that reached a maximum at $\sim 1$ hr. EGF had no effect on Fra- 2 and did not induce Fra-1 expression. NGF elicited a much longer increase in ERK phosphorylation (phospho-ERK was still detectable at $4 \mathrm{hr}$ ) and a more robust $c$-fos response than that induced by EGF, although the time course for the $c$-fos response was similar for both growth factors. In contrast to EGF, NGF induced a delayed Fra-2 response after $4 \mathrm{hr}$. Delayed Fra-1 expression also was induced by NGF. The possibility was tested that the high dose of EGF used in these experiments was suboptimal for eliciting changes in Fra-1 and Fra-2 responses (Greenberg et al., 1985). EGF consistently induced rapid phosphorylation of ERK yet failed to increase Fra-1 (data not shown) or Fra-2 expression across a wide concentration range (Fig. 7). Thus, NGF and EGF have markedly different effects on transcription factor expression in PC12 cells, which directly correlate with the differences in the duration of ERK phosphorylation.

\section{DISCUSSION}

This study used a novel experimental approach to identify a long-term increase in DNA binding activity of a Fra-2/JunD AP-1 complex associated with the differentiative growth factor NGF, but not with the mitogenic factor EGF. AP-1 activity generally is associated with cell proliferation and transformation (for review, see Angel and Karin, 1991). However, the effects of AP-1 on transcription are highly dependent on the composition of the AP-1 complex (Suzuki et al., 1991). AP-1 is a heterodimeric or homodimeric protein complex containing products of the $c$-jun and $c$-fos proto-oncogene family. Fos proteins include $c$-fos, FosB, $\Delta$ FosB, Fra-1, and Fra-2. The Jun family is composed of c-Jun 
and its homologs v-Jun, JunB, and JunD. Members of the Fos and Jun family contain leucine zipper motifs and can form heterodimers; the Jun family can homodimerize also. In addition, these proteins can interact with non-AP-1 proteins containing leucine zipper motifs (for review, see Foletta, 1996). Although c-fos and c-Jun both are associated strongly with cell proliferation induced by a variety of mitogens such as serum, EGF, and other mitogenic growth factors, evidence suggests that Fra-2 may be an important signaling component in development and differentiation (for review, see Angel and Karin, 1991; Foletta, 1996). For example, in myeloma cell lines, 8Br-cAMP triggers increased Fra-2 levels and concomitant enhancement of the DNA binding activity of a Fra-2/JunD complex, together with cell cycle arrest (Rezzonico et al., 1995). In osteoblasts, Fra-2 levels increase with differentiation, and inhibition of Fra-2 function inhibits differentiation (McCabe et al., 1996). Paradoxically, Fra-2 also has been implicated in cellular transformation and proliferation in chick embryo fibroblasts (Nishina et al., 1990; Foletta et al., 1994). However, Fra-2 is nontransforming in rodent fibroblasts. Evidence suggests that a $\mathrm{C}$-terminal transactivation domain that is present in some members of the AP-1 family, but not Fra-2, is required for transformation in rodent cells, but not avian cells (Wisdom and Verma, 1993). Thus, species-specific factors may determine the function of Fra-2 as a proliferative versus differentiative agent. An additional determinant of Fra-2 function could be its Jun family partner. c-Jun cooperates with ras to transform cells, but JunD suppresses ras-induced transformation (Pfarr et al., 1994). In chick embryo fibroblasts Fra-2/c-Jun diminishes transcription, but Fra-2/JunD enhances transcriptional activity (Suzuki et al., 1991). The Fra-2/c-Jun complex is crucial to transformation in these cells (Nishina et al., 1990; Suzuki et al., 1994). In other cells, Fra-1, but not Fra-2, complexes with c-Jun to mediate transformation (Mechta et al., 1997). Thus, transcriptional regulation by complexes of Fra-1 or Fra- 2 with c-Jun may be a key to transformation. In contrast, the present findings, together with those of other investigators (Rezzonico et al., 1995; McCabe et al., 1996), suggest that the Fra-2/JunD complex is associated with conditions in which the cell cycle is arrested.

In PC12 cells NGF, but not EGF, increases the expression of a 45-46 kDa form of Fra-2 and concomitantly alters its DNA binding activity. Both changes in expression level and posttranslational modifications, such as phosphorylation, alter the function of AP-1 proteins. Many stimuli, including phorbol esters, serum, and growth factors, increase both the expression levels and phosphorylation of AP-1 proteins, including Fra-2 (Yoshida et al., 1991; Gruda et al., 1994; Murakami et al., 1997, 1999). Serum or v-src-induced transformation elicits phosphorylation of Fra-2 in chick embryo fibroblasts (Yoshida et al., 1991; Suzuki et al., 1994; Murakami et al., 1999) and Swiss 3 T3 cells (Gruda et al., 1994). Phosphorylation changes the size of Fra-2 from $40 \mathrm{kDa}$ to multiple larger forms ranging between 43 and $48 \mathrm{kDa}$ (Yoshida et al., 1991; Gruda et al., 1994; Murakami et al., 1997, 1999; Treinies et al., 1999). The size of the Fra-2 protein that is induced by NGF in PC12 cells is consistent with a phosphorylated form of the protein. Phosphorylation is associated with increased mobility of Fra-2-containing complexes in EMSAs and with increased DNA binding activity (Gruda et al., 1994), similar to that observed in NGF-treated PC12 cells. It is likely that NGF-specific phosphorylation of Fra-2, together with its increased expression, is responsible for the increased DNA binding activity of Fra-2/JunD complexes to AP-1 and CREB-responsive elements in PC12 cells.

Evidence suggests that ERK signaling is essential for the phos- phorylation and increased expression of Fra-2 (Gruda et al., 1994; Murakami et al., 1997, 1999; Cook et al., 1999; Treinies et al., 1999). Cook et al. (1999) demonstrated that both transient and sustained ERK activation (as detected by its phosphorylation) can trigger $c$-fos expression, whereas sustained ERK signaling is necessary for the induction of Fra-1 and Fra-2. The present findings are in agreement with their report. EGF elicits a rapid brief ERK phosphorylation, together with $c$-fos expression, but no Fra-1 or Fra-2 expression. In contrast, NGF elicits a more sustained ERK phosphorylation and induces expression of $c$-fos, Fra-1, and Fra-2. The induction of the Fra-1 and Fra-2 is delayed, suggesting that they occur downstream of ERK activation. Several studies indicate that ERK signaling is responsible for the phosphorylation of Fra-1 and Fra-2. ERK is a substrate for MEK, and the MEK inhibitor PD098059 (Pang et al., 1995) blocks phosphorylation of Fra-1 and Fra-2 (Treinies et al., 1999). In addition, constitutively active MEK induces phosphorylation of Fra-2 (Murakami et al., 1999). Furthermore, there is evidence that ERK itself phosphorylates Fra-1 and Fra-2 (Gruda et al., 1994; Murakami et al., 1997).

Not only is ERK activity involved in phosphorylation of these protein, it also is necessary for their increased expression (Murakami et al., 1999; Treinies et al., 1999). The Fra-2 promoter is regulated via two AP-1 sites and a CRE (Yoshida et al., 1993; Sonobe et al., 1995), and these sites are responsible for Fra-2 upregulation in response to ERK signaling (Murakami et al., 1997, 1999). In fibroblasts during response to serum, the AP-1 consensus sites in the Fra-2 promoter are occupied successively by different AP-1 combinations. A complex of $c$-fos/c-Jun binds from 1-2 hr after stimulation, followed by Fra-2/c-Jun binding (Sonobe et al., 1995). A similar pattern of transactivation could occur in NGF-treated PC12 cells. After NGF or EGF treatment $c$-fos is upregulated. However, the $c$-fos response is much greater for NGF than for EGF and potentially could produce a greater transactivation of the Fra-2 promoter. In addition, Fra-2 autoregulates its own promoter activity. ERK phosphorylation of Fra-2 converts it to a more efficient transcriptional activator, permitting positive autoregulation of the Fra-2 promoter (Murakami et al., 1997, 1999). A positive autoregulatory loop would permit a continuous long-term enhancement of Fra-2 expression such as that observed in PC12 cells after NGF treatment.

The present work demonstrates that NGF, but not EGF, induces a sustained upregulation and phosphorylation of the Fra-2 protein, together with an increase in DNA binding activity of the

Table 1. NGF-sensitive late-response gene products, transcriptionally regulated in PC12 cells via AP-1- or CREB-binding sites
(1) Latexin ${ }^{a}$
(2) IL- $1 \alpha^{b}$
(3) Choline acetyltransferase ${ }^{c}$
(4) Neurofilament, light (NF-L) ${ }^{d}$
(5) Neuropeptide Y (NP-Y) ${ }^{e}$
(6) $\mathrm{VGF}^{f}$
(7) Dopamine $\beta$-hydroxylase ${ }^{g}$
(8) Tyrosine hydroxylase ${ }^{h}$

Shown are proteins for which expression levels or mRNA levels are upregulated by NGF in PC12 cells and for which AP-1 proteins and/or AP-1- or CREB-binding elements in respective gene promoter regions are implicated in controlling transcription. All of the proteins listed are products of late-response genes PC12 cells. ${ }^{a}$ Miyasaka et al., 1999; ${ }^{b}$ Alheim et al., 1996; ${ }^{c}$ Bejanin et al., 1992; Pongrac and Rylett, 1998; ${ }^{d}$ Reeben et al., 1995; ${ }^{e}$ Holliday et al., 1995; ${ }^{f}$ D'Arcangelo et al., 1996; Di Rocco et al., 1997; Luc and Wagner, 1997; ${ }^{g}$ Huang and Kao, 1996; Swanson et al., 1998; ${ }^{h}$ Gizang-Ginsberg and Ziff, 1990; Nagamoto-Combs et al., 1997. 
Fra-2/JunD complex in PC12 cells. These data support a hypothesis that growth factors coupled to sustained ERK activity upregulate protein expression at the transcriptional level via Fra-2/ JunD transactivation of AP-1 and CREB sites. Such sites are common in a variety of NGF-regulated late-response genes in PC12 cells, such as those listed in Table 1. For some of these genes, such as interleukin-1 $\alpha$ (IL-1 $\alpha$; Alheim et al., 1996), neuropeptide Y (NP-Y; Holliday et al., 1995), and VGF (D'Arcangelo et al., 1996; Di Rocco et al., 1997; Luc and Wagner, 1997), AP-1 proteins or AP-1 and/or CREB sites in the promoters are strongly implicated in NGF responsiveness. Furthermore, VGF (Salton et al., 1991) and rat light neurofilament (NF-L; Reeben et al., 1995) are upregulated differentially by NGF over EGF. N-type $\mathrm{Ca}^{2+}$ channels also are upregulated selectively in PC12 cells by NGF (Colston et al., 1998). Although the rat promoter sequence is not available, the human promoter for these channel subunits contains two AP-1 binding sites (Kim et al., 1997). Thus, the Fra-2/JunD complex could act as a broad regulatory control switch that regulates transcription and promotes differentiation in PC12 cells.

\section{REFERENCES}

Abmayr SM, Workman JL (1989) Preparation of nuclear and cytoplasmic extracts from mammalian cells. In: Current protocols in molecular biology (Ausubel FM, Brent R, Kingston RE, eds), pp 12.2.1-12.2.10. New York: Breene and Wiley-Interscience.

Alheim K, McDowell TL, Symons JA, Duff GW, Bartfai T (1996) An AP-1 site is involved in the NGF induction of IL- $1 \alpha$ in PC12 cells. Neurochem Int 29:487-496.

Angel P, Karin M (1991) The role of Jun, Fos, and the AP-1 complex in cell proliferation and transformation. Biochim Biophys Acta 1072:129-157.

Angel P, Imagawa M, Chiu R, Stein B, Imbra RJ, Rahmsdorf HJ, Jonat C, Herrlich P, Karin M (1987) Phorbol ester-inducible genes contain a common cis element recognized by a TPA-modulated trans-acting factor. Cell 49:729-739.

Bejanin S, Habert E, Berrard S, Dumas J-B, Edwards M, Loeffler J-P, Mallet J (1992) Promoter elements of the rat choline acetyltransferase gene allowing nerve growth factor inducibility in transfected primary cultured cells. J Neurochem 58:1580-1583.

Blackwell TK, Weintraub H (1990) Differences and similarities in DNA binding preferences of $\mathrm{MyoD}$ and E2A protein complexes revealed by binding site selection. Science 250:1104-1110.

Blumberg D, Radeke MJ, Feinstein SC (1995) Specificity of nerve growth factor signaling: different patterns of early tyrosine phosphorylation events induced by NGF, EGF, and bFGF. J Neurosci Res 41:628-639.

Chao MV (1992) Growth factor signaling: where is the specificity? Cell 68:995-997.

Chen RH, Sarnecki C, Blenis J (1992) Nuclear localization and regulation of erk- and rsk-encoded protein kinases. Mol Cell Biol 12:915-927.

Colston JT, Valdes JJ, Chambers JP (1998) $\mathrm{Ca}^{2+}$ channel $\alpha_{1}$-subunit transcripts are differentially expressed in rat pheochromocytoma (PC12) cells following nerve growth factor treatment. Int J Neurosci 16:379-389.

Comb M, Birnberg NC, Seasholtz A, Herbert E, Goodman HM (1986) A cyclic AMP- and phorbol ester-inducible DNA element. Nature 323:353-358.

Cook SJ, Aziz N, McMahon M (1999) The repertoire of Fos and Jun proteins expressed during the $\mathrm{G}_{1}$ phase of the cell cycle is determined by the duration of mitogen-activated protein kinase activation. Mol Cell Biol 19:330-341.

D'Arcangelo G, Habas R, Wang S, Helgoua S, Salton SRJ (1996) Activation of codependent transcription factors is required for transcriptional induction of the $v g f$ gene by nerve growth factor and ras. Mol Cell Biol 16:4621-4631.

Delegeane AM, Ferland LH, Mellon PL (1987) Tissue-specific enhancer of the human glycoprotein hormone $\alpha$-subunit gene: dependence on cyclic AMP-inducible elements. Mol Cell Biol 7:3994-4002.

Dignam JD, Lebovitz RM, Roeder RG (1983) Accurate transcription initiation by RNA polymerase II in a soluble extract from isolated mammalian nuclei. Nucleic Acids Res 11:1475-1489.

Di Rocco G, Pennuto M, Illi B, Canu N, Filocamo G, Trani E, Rinadli AM, Possenti R, Mandolesi G, Sirinian MI, Jucker R, Levi A, Nasi S (1997) Interplay of the E box, the cyclic AMP response element, and $\mathrm{HTF} / \mathrm{HEB}$ in transcriptional regulation of the neurospecific, neurotrophin-inducible $v g f$ gene. Mol Cell Biol 17:1244-1253.
Foletta VC (1996) Transcription factor AP-1, and the role of Fra-2. Immunol Cell Biol 74:121-133.

Foletta VC, Sonobe MH, Suzuki T, Endo T, Iba H, Cohen DR (1994) Cloning and characterization of the mouse fra-2 gene. Oncogene 9:3305-3311.

Fukuda M, Gotoh Y, Tachibana T, Dell K, Hattori S, Yoneda Y, Nishida E (1995) Induction of neurite outgrowth by MAP kinase in PC12 cells. Oncogene 11:239-244.

Gizang-Ginsberg E, Ziff EB (1990) Nerve growth factor regulates tyrosine hydroxylase gene transcription through a nucleoprotein complex that contains c-fos. Genes Dev 4:477-491.

Gogos JA, Hsu T, Bolton J, Kafatos FC (1992) Sequence discrimination by alternatively spliced isoforms of a DNA binding zinc finger domain. Science 257:1951-1955.

Greenberg ME, Geene LA, Ziff EB (1985) Nerve growth factor and epidermal growth factor induce rapid transient changes in protooncogene transcription in PC12 cells. J Biol Chem 260:14101-14110.

Greene LA, Kaplan DR (1995) Early events in neurotrophin signaling via Trk and p75 receptors. Curr Opin Neurobiol 5:579-587.

Greene LA, Tischler AS (1976) Establishment of a noradrenergic clonal line of rat adrenal pheochromocytoma cells which respond to nerve growth factor. Proc Natl Acad Sci USA 73:2424-2428.

Gruda MC, Kovary K, Metz R, Bravo R (1994) Regulation of Fra-1 and Fra-2 phosphorylation differs during the cell cycle of fibroblasts, and phosphorylation in vitro by MAP kinase affects DNA binding activity. Oncogene 9:2537-2547.

Holliday N, Babli D, Pance A, Allen JM (1995) Nerve growth factor regulation of a late response gene-neuropeptide Y. Biochem Soc Trans 23:226.S.

Huang C-M, Kao L-S (1996) Nerve growth factor, epidermal growth factor, and insulin differentially potentiate ATP-induced $\left[\mathrm{Ca}^{2+}\right]_{\mathrm{i}}$ rise and dopamine secretion in PC12 cells. J Neurochem 66:124-130.

Kim DS, Jung H-H, Park S-H, Chin H (1997) Isolation and characterization of the $5^{\prime}$-upstream region of the human $\mathrm{N}$-type calcium channel $\alpha_{1 \mathrm{~B}}$ subunit gene. J Biol Chem 272:5098-5104.

Lee W, Mitchell P, Tjian R (1987) Purified transcription factor AP-1 interacts with TPA-inducible enhancer elements. Cell 49:741-752.

Luc P-VT, Wagner JA (1997) Regulation of the neural-specific gene VGF in PC12 cells. J Mol Neurosci 8:223-241.

Marshall CJ (1995) Specificity of receptor tyrosine kinase signaling: transient versus sustained extracellular signal-related kinase activation. Cell 80:179-185.

McCabe LR, Banerjee C, Kundu R, Harrison RJ, Dobner PR, Stein JL, Lian JB, Stein GS (1996) Developmental expression and activities of specific Fos and Jun proteins are functionally related to osteoblast maturation: role of Fra-2 and JunD during differentiation. Endocrinology 137:4398-4408.

Mechta F, Lallemand D, Pfarr, Yaniv M (1997) Transformation by ras modifies AP-1 composition and activity. Oncogene 14:837-847.

Miyasaka N, Hatanaka Y, Jin M-H, Arimatsu Y (1999) Genomic organization and regulatory elements of the rat latexin gene, which is expressed in a cell type-specific manner in both central and peripheral nervous systems. Brain Res Mol Brain Res 69:62-72.

Murakami M, Sonobe MH, Ui M, Kabuyama Y, Watanabe H, Wada T, Handa H, Iba H (1997) Phosphorylation and high level expression of Fra-2 in v-src transformed cells: a pathway of activation of endogenous AP-1. Oncogene 14:2435-2444.

Murakami M, Ui M, Iba H (1999) Fra-2-positive autoregulatory loop triggered by mitogen-activated protein kinase (MAPK) and Fra-2 phosphorylation sites by MAPK. Cell Growth Differ 10:333-342.

Nagamoto-Combs K, Piech KM, Best JA, Sun B, Tank AW (1997) Tyrosine hydroxylase gene promoter activity is regulated by both cyclic AMP-responsive element and AP-1 sites following calcium influx. J Biol Chem 272:6051-6058.

Nguyen TT, Scimeca J-C, Filoux C, Peraldi P, Carpentier J-L, Van Obberghen E (1993) Co-regulation of the mitogen-activated protein kinase, extracellular signal-regulated kinase 1 , and the $90 \mathrm{kDa}$ ribosomal S6 kinase in PC12 cells. J Cell Biol 268:9803-9810.

Nishina H, Sato H, Suzuki T, Sato M, Iba H (1990) Isolation and characterization of $\mathrm{rra}-2$, an additional member of the fos gene family. Proc Natl Acad Sci USA 87:3619-3623.

Pang L, Sawada T, Decker SJ, Saltiel AR (1995) Inhibition of MAP kinase kinase blocks the differentiation of PC -12 cells induced by nerve growth factor. J Biol Chem 270:13585-13588.

Pfarr CM, Mechta F, Spyrou G, Lallemand D, Carillo S, Yaniv M (1994) Mouse JunD negatively regulates fibroblast growth and antagonizes transformation by ras. Cell 76:747-760.

Pongrac JL, Rylett JR (1998) NGF induction of the expression of ChAT mRNA in PC12 cells and primary cultures of embryonic rat basal forebrain. Brain Res Mol Brain Res 62:25-34.

Qiu M-S, Green SH (1992) PC12 cell neuronal differentiation is associated with prolonged p 21 ras activity and consequent prolonged ERK activity. Neuron 9:705-717.

Reeben M, Neuman T, Palgi K, Paalme V, Sarma M (1995) Characterization of the rat light neurofilament (NF-L) gene promoter and iden- 
tification of NGF and cAMP responsive regions. J Neurosci Res 40:177-188.

Rezzonico R, Loubat A, Lallemand D, Pfarr C, Far DF, Proudfoot A, Rossi B, Ponzio G (1995) Cyclic AMP stimulates a JunD/Fra-2 AP-1 complex and inhibits the proliferation of interleukin-6-dependent cell lines. Oncogene 11:1069-1078.

Salton SRJ, Fischberg DJ, Dong K-W (1991) Structure of the gene encoding VGF, a nervous system-specific mRNA that is rapidly and selectively induced by nerve growth factor in PC12 cells. Mol Cell Biol 11:2335-2349.

Sassone-Corsi P, Ransone LJ, Verma IM (1990) Cross-talk in signal transduction: TPA-inducible factor jun/AP-1 activates cAMPresponsive enhancer elements. Oncogene 5:427-431.

Shapiro DJ, Sharp PA, Wahli WW, Keller MJ (1988) A high-efficiency HeLa cell nuclear transcription extract. DNA 7:47-55.

Sonobe MH, Yoshida T, Murakami M, Kameda T, Iba H (1995) fra-2 promoter can respond to serum stimulation through AP-1 complexes. Oncogene 10:689-696.

Sun X-H, Baltimore D (1991) An inhibitory domain of E12 transcription factor prevents DNA binding in E12 homodimers, but not in E12 heterodimers. Cell 64:459-470.

Suzuki T, Okuno H, Yoshida T, Endo T, Nishina H, Iba H (1991) Difference in transcriptional regulatory function between $c$-fos and Fra-2. Nucleic Acids Res 19:5537-5542.

Suzuki T, Murakami M, Onai N, Fukuda E, Hashimoto Y, Sonobe MH, Kameda T, Ichinose M, Miki K, Iba H (1994) Analysis of AP-1 function in cellular transformation pathways. J Virol 68:3527-3535.

Swanson DJ, Zellmer E, Lewis EJ (1998) AP-1 proteins mediate the
cAMP response of the dopamine $\beta$-hydroxylase gene. $\mathrm{J}$ Biol Chem 273:24065-24074.

Traverse S, Seedorf K, Paterson H, Marshall CJ, Cohen P, Ullrich A (1994) EGF triggers neuronal differentiation of PC12 cells that overexpress the EGF receptor. Curr Biol 4:694-701.

Treinies I, Paterson HF, Hooper S, Wilson R, Marshall CJ (1999) Activated MEK stimulates expression of AP-1 components independently of phosphatidylinositol 3-kinase (PI3-kinase) but requires a PI3-kinase signal to stimulate DNA synthesis. Mol Cell Biol 19:321-329.

Wasylyk B, Hahn SL, Giovane A (1993) The Ets family of transcription factors. Eur J Biochem 211:7-18.

Wells A (1999) Molecules in focus. EGF receptor. Int J Biochem Cell Biol 31:637-643.

Whitmarsh AJ, Davis RJ (1996) Transcription factor AP-1 regulation by mitogen-activated protein kinase signal transduction pathways. J Mol Med 74:589-607.

Wingender E, Chen X, Hehl R, Karas H, Liebach I, Matys V, Meinhardt T, Prüss M, Reuter I, Schacherer F (2000) TRANSFAC: an integrated system for gene expression regulation. Nucleic Acids Res 28:316-319.

Wisdom R, Verma IM (1993) Transformation by Fos proteins requires a C-terminal transactivation domain. Mol Cell Biol 13:7429-7438.

Yamada M, Ikeuchi T, Aimoto S, Hatanaka H (1996) PC12h-R cell, a subclone of PC12 cells, shows EGF-induced neuronal differentiation and sustained signaling. J Neurosci Res 43:355-364.

Yoshida T, Sato H, Iba H (1991) Transcription of fra-2 mRNA and phosphorylation of Fra-2 protein are stimulated by serum. Biochem Biophys Res Commun 174:934-939.

Yoshida T, Suzuki T, Sato H, Nishina H, Iba H (1993) Analysis of fra-2 gene expression. Nucleic Acids Res 21:2715-2721. 